\title{
Impact of Advanced Transport Machinery for Reducing Drudgery and Work Related Stress of Farm Women
}

\author{
Rekha Tiwari ${ }^{* 1}$, D. S. Tomar ${ }^{1}$, A. K. Dixit ${ }^{2}$ and A. K. Saxena ${ }^{3}$ \\ ${ }^{1,2}$ KVK, Rajmata Vijaya Raje Scindia Krishi Vishwavidyalaya, Krishi Vigyan Kendra, Ujjain. M.P. (456 010), India \\ ${ }^{3}$ JNKVV, Ganjbasoda, M.P. (464 221), India
}

\section{Article History}

Manuscript No. AR1114b

Received in $24^{\text {th }}$ November, 2014

Received in revised form $18^{\text {th }}$ March, 2015

Accepted in final form $4^{\text {th }}$ April, 2015

\section{Correspondence to}

"E-mail: rekhaup_2007@rediffmail.com

\section{Keywords}

drudgery, musculo-skeletal problem, posture, $\mathrm{VO}_{2}$, women friendly

\begin{abstract}
Agriculture is the highest employer of women's labour to the extent of $76 \%$ in India. Moreover, farm women are doing arduous field operations along with household chores, mostly using traditional hand tools and gadgets which are the source of drudgery and causes low efficiency of farm women. In this regard based on the feedback received by the farm women an excellent research was conducted. Hence, the emphasis given here to reduce the drudgery among farm women by introducing the women friendly farm equipment, which is especially designed for them. The present study was conducted at village Salakhedi (District-Ujjain) M.P. (India) by covering 30 farm women for assessing the drudgery involved in the farm activity-transport of harvested wheat crop from the field to threshing flour in 2012-13 and 2013-14. A specially women friendly multipurpose trolly was designed and developed by the Krishi Vigyan Kendra, (RVSKVV) Ujjain (M.P.). The different parameters like drudgery involved in the selected activity, perceived exertion, difficulty, muscular problems etc. were studied. Three treatments were selected for the assessing data $\mathrm{T}_{1}, \mathrm{~T}_{2}$ and $\mathrm{T}_{3}$. The results indicated that $\mathrm{T}_{3}$ (with trolly) technology reduced the drudgery by $12 \%$ as compare to the $\mathrm{T}_{1}$. Body muscular pain also reduced particularly at cervical and fingers palm ${ }^{-1}$. Output in terms of $\mathrm{kg}$ was also high in $\mathrm{T}_{3}$ (extra $90.5 \mathrm{~kg} \mathrm{hr}^{-1}$ ). Even it removes the body etching and burning problem faced by the farm women which was the extreme problem quoted by the farm women.
\end{abstract}

\section{Introduction}

In India, rural women play a major role in shaping the economy of the country. They share abundant responsibilities by performing wide spectrum of duties both in home and outside but their participation is considered as normal by the society. The devotion and contribution of women farmers to the Indian agriculture is enormous. Women, who are almost half of our total population and contribute monetary and nonmonetary inputs towards national income, however, occupy low position in the socio economic Index of India. Rural Indian women are extensively involved in agricultural activities and moreover, farm women are doing arduous field operations along with household chores, mostly using traditional equipments/tools which are not only the source of drudgery but also a major cause of low efficiency and output. Hence, it is the need of the hour to give attention adequately to the realities of these rural women's life and to assist them in obtaining equal access to resources and farm technologies and make agriculture women friendly.

In broad terms, the feminization of agriculture refers to women's increasing participation in the agricultural labour force, whether as independent producers, as unremunerated family workers, or as agricultural wage workers. Women work not only in the fields, but also in agricultural processing and packing plants. Katz (2003) and Deere (2005) provide more specific definitions for the feminization of agriculture as; an increase in women's participation rates in the agricultural sector, either as self-employed or as agricultural wage workers; in other words, an increase in the percentage of women who are economically active in rural areas, and / or an increase in the percentage of women in the agricultural labour force relative to men, either because more women are working and / or because fewer men are working in agriculture. Before discussing about drudgery one should know what are drudgery prone farm activities Drudgery is generally conceived as physical and mental strain, agony and monotony and hardship experienced 
by human being. Farm activities in which the drudgery is involved are sowing, manually uprooting, weeding, harvesting, winnowing, de husking, shelling, pounding, grinding of cereals and pulses by manual method, Cutting, collecting and carrying fuel/fodder over long distance and excessive physical work in care and management, harvesting, threshing, processing and marketing etc. Long hours of work put in by women fulfilling their multiple roles hardly leave any time for leisure which ultimately gives ill effect on their both mental and physical, Badve (1999), and all most all farm women suffer physical drudgery in various operations in agriculture. Study on rice farming revealed that transplanting, threshing, parboiling are the heavy activities whereas weeding, cutting and carrying were the moderately heavy activities (Anonymous, 2004).

Ergonomical characteristics of farm women give information on capacity of a person to work at different comfort levels and include anthropometric data, muscular strength and maximum aerobic capacity. As per the Kulkarni and Gite (2009) the women have different ergonomical characteristics than men. Therefore, to make the equipment suitable for women workers, due and keen attention needs to be given, to match their capabilities and limitations, while designing equipment for use by women for various operations. Dipankar (2009) also studied on drudgery reducing technologies for farm women and mentioned that a large no. of farm operations have taken place in the country. However most of the technologies have been designed with general concept of male being main users. However, the technological needs of female operators are different due to different in ergonomical characteristics, operational skills and experience and related factors. The technologies so designed are often unsuitable for women causing fatigue, distress or even cause operational difficulties. Hence, it is necessary to provide the knowledge regarding introduction and adoption of labour saving and drudgery reducing technologies and methods to alleviate the suffering of farm women in agriculture works which would enable the rural women to participate more energetically and enthusiastically.

It is imperative to provide the knowledge regarding introduction and adoption of labour saving and drudgery reducing technologies and methods to alleviate the suffering of farm women in agriculture works which would be enable the rural women to participate more energetically and enthusiastically. Among all the farm activities lifting of harvested wheat crop from field and carrying it up to the place of threshing was very tedious task and full of drudgery. It affects the skin of farm women due to the very minute and delicate awns of harvested wheat plant. It gives a scorching and itching problem to farm women due to the presence of certain allergens. Muscular pain is a typical feature noticed and reported by women workers in traditional method. Keeping these facts in view, the present study was conducted in which especially multipurpose trolley was designed and developed to assess the drudgery involved during lifting of harvested crop from field, the perceived exertion on muscles and to provide a practical solution to the menace by introducing the women friendly equipment/tool through feedback and consensus.

\section{Materials and Methods}

The study was conducted in a village Salakhedi (29 km away from District-Ujjain) the adopted cluster area of KVK-Ujjain India. Trial was conducted in the year 2013 and 2014 during Rabi. Randomly 30 farm women performing the harvesting and transporting of harvested produce of wheat crop was selected. In the said village, On-Farm Trials (OFT) followed by Front-Line Demonstrations (FLDs) was conducted for reducing drudgery of farm women. Comparative study was carried out in improved technology which was designed and developed by KVK, Ujjain (manually hand drawn trolly) and existing practice (carrying harvested produce on heads) for assessing the drudgery involved in the activities. Well prepared proforma was used for assessing the data regarding drudgery involved in the farm activity-lifting of harvested wheat crop. While conducting the study special attention was given on the selected sample size with regards to their physical fitness and ensuring that none had any serious health hazard. These precautions were specially taken for assessing the correct data while selecting the farm women.

\subsection{Participatory mechanization of planning and evaluation}

The conventional "top-down" approach to extension has not generally yielded positive results, hence the participatory research concept, which has its roots in the recognition that if smallholder farmers do not perceive the relevance of the results of research to their own situation, they will not adopt them. Participatory research transfers the initiative and the power of decision to farmers who, in the final analysis, have significant advantages over scientists because they have detailed and practical knowledge of their own production systems. It involves the active participation of all stakeholders in planning and implementing mechanization strategies, with the role of farmers taking on paramount importance. Participatory planning builds upon the indigenous knowledge that already exists in the community and blends it with the ideas and knowledge of other stakeholders e.g. researchers, policy makers, private sector, etc. Based on the problems emerging among the farm women during the Participatory Rural Appraisal (PRA) of village Salakhedi, design, size, weight and cost involved in fabricating a manually operated trolley was finalized.

\subsection{Preplanned questionnaire}

A specially designed and well planned questionnaire was 
prepared for assessing the data regarding the selected farm activity. It covers all the required information viz., time, degree of difficulty, and frequency of performance, RPE (Rate of Perceived Exertion) and muscular problem as well as the output. Even the feedback was also noticed for the more refinement in the technology and for better future of women friendly equipments based upon the self experience of the particular farm women towards the drudgery prone farm activity for making it simple/ convenient along with the better output.

\subsection{Selection of sample}

\subsubsection{Age group}

The farm women were selected randomly and criteria of age group were selected below 40 years purposively. All the farm women were well experienced regarding all the farm activities.

\subsubsection{Description of technology}

$\mathrm{T}_{1}$-Existing Method: In this method the farm women lift the harvested wheat crop from the field and carry the load on head or in hand tied by tiny ropes and lifting the bundles on head or back.

$\mathrm{T}_{2}$-Manually Hand Drawn Multipurpose Trolley (Improved Technology): Especially designed women-friendly multipurpose hand drawn Trolley was designed and developed by the Krishi Vigyan Kendra, (RVSKVV) Ujjain (M.P.) for transporting the harvested crop-wheat was used for the study. It was compared with the existing practice (manually lifting of the wheat bundles).

$\mathrm{T}_{3}$-Refined Trolley with larger wheel diameter: In this slight modification was made by increasing the base and diameter of the wheel, size and inclination angle of handle and its height was adjusted to suit women of different height, based upon the feedback received by the farm women to suit to their convenience and simply the work demanding less energy. The base of trolley was provided with small perforation to facilitate its use in carrying and pre-cleaning the horticulture crops before marketing and thus making it suitable for wider adaptability.

\subsection{Factors influencing drudgery}

\subsubsection{Degree of difficulty}

Degree of difficulty was measured on five point scale ranging from very easy to very difficulty.

\subsubsection{Time}

One hr. (60 minutes) observations were made in all the practices for assessing and for comparing the data.

\subsubsection{Frequency}

Frequency of performance was measured on five point scale varies from daily to seasonally. Evaluation of Drudgery:
Drudgery Index was calculated by using the formula given below.

\subsubsection{Drudgery Index}

$(\mathrm{X}+\mathrm{Y}+\mathrm{Z} / 3) \times 100$

Whereas, $X$ : co-efficient of frequency,

Y: co-efficient of Difficulty and

$\mathrm{Z}$ : co-efficient of time.

\section{5. $R P E$}

Rate of Perceived Exertion was measured on five point scales ranging from very easy to very difficulty.

\subsection{Physical fitness}

Physical fitness of the respondent was calculated by using the following formula.

$\mathrm{VO}_{2}$ max.(mil ${ }^{-1}$ min.) means Volume of Oxygen consumption ${ }^{1} \mathrm{~min}=\mathrm{VO}_{2} \max \left(\mathrm{lit}^{-1} \mathrm{~min}\right.$. $) /$ Body wt $(\mathrm{kg}) \times 1000$ and categorized as Poor (<15), Low Average (16-25), High Average (26-30), Good (31-40), Very Good (41-45) and Excellent (>45).

\subsection{Muscular pain}

Incidence of musculo-skeletal problems of the selected subjects was identified by using the 'body map'. After completing the activity incidence of body pain at body parts viz., upper extremities and lower extremities was recorded on five point scale i.e. very severe to very light.

\subsection{Feed back}

Feed back of the technology was received after completing the activity. After using the trolley a simple questions were asked to the selected farm women regarding the advanced and designed trolley with compare to the existing practice. Based on their experience the refined trolley was again designed.

\section{Results and Discussion}

\subsection{Personal characteristics and socio-economic analysis}

The detail information of selected farm women as depicted in Table 1 which reveal that maximum farm women (40\%) belonged to age group 31-35 years followed by (30\%) between 26-30 years category whereas $16.66 \%$ were in the age group of $35-40$ years. Only $13.33 \%$ were in $20-25$ years age group represented the youths. The mean age was 30 ; SD was 4.56 with a variance of 20.85 indicating that the group was moderately heterogeneous. In case of body weight, it was observed that maximum women were having weight up to $45 \mathrm{~kg}(46.66 \%)$ followed by $26.66 \%$ dwelt in $35-40 \mathrm{~kg}$ range whereas only 07 women's weight was between $46-50 \mathrm{~kg}$ and only one woman whose weight was more than $50 \mathrm{~kg}$. Further, analyzing the Body Mass Index (BMI), it was evident that, malnutrition was very common problem in village Salakhedi across all the age groups and this can be theoretically concluded looking 
in to their literacy status as only $3.33 \%$ respondents were matriculate and not a single graduate was found. Majority of the women had no education or were school dropouts beyond primary level and $13.33 \%$ studied up to middle school and only one lady had completed high school education. It was also quite true that illiteracy level was still remarkably poor in rural area; the studies showed $36.66 \%$ were not educated. Tandon (1993) studied on 100 socially underprivileged women in the age group of $25-50$ yrs found that $83 \%$ of women were illiterate, $13 \%$ had studied up to primary school and only $4 \%$ had studied up to secondary school. Similarly, major drawback of women education was related to drop outs and stagnation. As compared to boys, girl's dropout ratio was more due to social taboo, early marriage and cooperates in the earnings of the household. In general, a large workforce employed in industries and many other occupations comprised men as well as women. She stated that because of their low literacy level, large section of the employed women folk was compelled to take up jobs in the unorganized sector.

As regards to the family back ground of the farm ladies the

\begin{tabular}{lccccc}
\hline $\begin{array}{l}\text { Table 1: Personal characteristics and family background of } \\
\text { the farm women. (N=30) }\end{array}$ \\
\hline $\begin{array}{l}\text { Param- } \\
\text { eters }\end{array}$ & Details & $\begin{array}{c}\text { No. of Re- } \\
\text { spondents } \\
\text { (N=30) }\end{array}$ & $\begin{array}{c}\text { Per- } \\
\text { cent- } \\
\text { age }\end{array}$ & $\begin{array}{c}\text { Mean } \\
\pm \text { SD }\end{array}$ & $\begin{array}{c}\text { Vari- } \\
\text { ance }\end{array}$ \\
\hline Age & $20-25$ & 04 & 13.33 & 30.00 & 20.85 \\
(Yr) & $26-30$ & 09 & 30.00 & \pm & \\
& $31-35$ & 12 & 40.00 & 4.56 & \\
& $35-40$ & 05 & 16.66 & & \\
\hline Weight & $35-40$ & 08 & 26.66 & 43.0 & 17.44 \\
(kg) & $41-45$ & 14 & 46.66 & \pm & \\
& $46-50$ & 07 & 23.33 & 4.17 & \\
& $50<$ & 01 & 03.33 & & \\
\hline Literacy & Illiterate & 11 & 36.66 & 2.1 & 4.99 \\
level & Up to primary & 14 & 46.66 & \pm & \\
& Middle school & 04 & 13.33 & 2.23 & \\
& High school & 01 & 03.33 & & \\
& College & 00 & - & & \\
\hline Type of & Nuclear & 18 & 60.00 & - & - \\
Family & Joint & 12 & 40.00 & & \\
\hline No. of & $1-3$ & 04 & 13.33 & 5.36 & \\
Mem- & $4-6$ & 18 & 60.00 & \pm & 2.51 \\
bers & $>7$ & 08 & 26.66 & 1.58 & \\
\hline Cultivat- & $0.5-1$ & 17 & 56.7 & 1.71 & \\
ed land & $1.0-3.0$ & 09 & 30.0 & \pm & 1.68 \\
(ha) & 3.0 and more & 04 & 13.3 & 1.29 & \\
\hline Annual & $40-60$ & 09 & 30.0 & 71 & \\
income & $60-80$ & 15 & 50.0 & \pm & \\
(₹ '000 ) & 80 and more & 06 & 20.0 & 14016 & \\
\hline & & & & & \\
\hline
\end{tabular}

result indicate that $60 \%$ were from nuclear family where as $40 \%$ still live under the joint family system. From the finding it was clear that nuclear family system has now a day has percolated in the rural areas, mainly due to fragmentation of holdings and other socio-economic reasons. But as regards to the family members still $60 \%$ house hold have 4 to 6 members while $26.66 \%$ had up to 7 members in their family. Another reason which is closely related is the size of land holdings. Maximum respondents (56.7\%) were small farmers having up to one hectare land followed by $30 \%$ up to 3 ha and only $13 \%$ having more than 03 ha holding. This has been appropriately reflected in their economic status, as about $80 \%$ respondents have their annual income below 0.8 lacs and only $20 \%$ had a satisfactory income.

\subsection{Physical fitness}

Volume of oxygen consumption of the respondents was also calculated for assessing the physical fitness of the particular farm women (Table 2.) and it was observed that maximum 17 respondents $(60 \%)$ had good quality of $\mathrm{VO}_{2} \max \left(\mathrm{ml}^{-1}\right.$ minute) whereas 10 respondents $(33.33 \%)$ dwelt in very good category and only one $(3.33 \%)$ farm women came under excellent category and high average category respectively. This implies that age factor plays important role as there is an increases in the $\mathrm{Vo}_{2}$ max with age and decrease at older age. Similar study has also been reported by Saha (1990).

\subsection{Drudgery related study}

Parameters related to drudgery index as (Table 3 ) for observing and analyzing the study all the related parameters viz., time, frequency of performance and degree of difficulty was assessed in detail for calculating the drudgery Index for selected farm activity. For assessing the data fixed time was 60 min was allotted in each treatment and each respondent. Frequency and degree of difficulty was also calculated on five point scale. Based on time, frequency of performance and difficulty the drudgery index was calculated for the selected farm activity. It was clear that maximum drudgery was assessed in $\mathrm{T}_{1}$ (exiting practice) i.e. $70.88 \%$ whereas in $\mathrm{T}_{2}$ (manually hand drawn multipurpose trolley) it was noted $65.22 \%$ and in $\mathrm{T}_{3}$ value

\begin{tabular}{|c|c|c|c|}
\hline $\begin{array}{l}\text { Sl. } \\
\text { No. }\end{array}$ & $\begin{array}{l}\text { Consumption rate } \mathrm{VO}_{2} \\
\text { max. }\left(\mathrm{ml}^{-1} \mathrm{~min}\right)\end{array}$ & $\begin{array}{l}\text { No. of } \\
\text { respondents }\end{array}$ & Percentage \\
\hline 1. & Poor $(<15)$ & Nil & Nil \\
\hline 2. & Low average (16-25) & Nil & Nil \\
\hline 3. & High average (26-30) & 01 & 3.33 \\
\hline 4. & Good (31-40) & 18 & 60.00 \\
\hline 5. & Very good (41-45) & 10 & 33.33 \\
\hline 6. & Excellent $(>45)$ & 01 & 3.33 \\
\hline
\end{tabular}


was $58.88 \%$. It means in $\mathrm{T}_{3}$ (refined trolley with larger wheel diameter) drudgery index was reduced up to $12 \%$. Perceived exertion (fatigue) was also high in $\mathrm{T}_{1}(4.73)$ as compare to $\mathrm{T}_{2}$ and $\mathrm{T}_{3}$. These findings are in agreement with the findings in different parts of the country as reported by different Researcher's enumerated below. Bhatnagar (1995) stated that physiological fatigue was one of the causative factors of drudgery. Workers physiological fatigue was apparent from the temporal rise in heart rate reaction and significantly higher pulse towards the end of the day's work. Further, the factors which influenced the physiological workload were weight of load, speed of walking, frequency of trip, distance covered and duration of the work. Boki, (2000) indicated that fetching water and collecting firewood scored high for perceived exertion i.e. 4.6 while preparing of food was rated least for perceived exertion i.e. 1.98 .

Other most important factors were area coverage $\left(\mathrm{m} \mathrm{hr}^{-1}\right.$.) and output $\left(\mathrm{kg} \mathrm{hr}^{-1}\right)$. Harvested wheat produce of $20.53 \mathrm{~kg} \mathrm{hr}^{-1}$ was carried out by single farm women in $\mathrm{T}_{1}$ by covering 24.43 $\mathrm{m} \mathrm{hr}^{-1}$, whereas in $\mathrm{T}_{2}$ it was increased by $102.73 \mathrm{~kg} \mathrm{hr}^{-1}$ with covering $36.63 \mathrm{~m}^{2}$ area hr-1. In case of $\mathrm{T}_{3}$ it was again more beneficial to the farm women in refined technology 111.03 $\mathrm{kg} \mathrm{hr}^{-1}$ load could be carried out by a single farm woman by covering $38.23 \mathrm{~m}$ area $\mathrm{hr}^{-1}$. It means in refined technology maximum output within one $\mathrm{hr}$ was $90.5 \mathrm{~kg} \mathrm{hr}^{-1}$ extra than the existing practice which was manually lifted by a farm women. By using this technology they can save 2-3 days on particular activity. In case of load carrying manually by a women was studied by Bhatnagar A. (1995) on construction workers and conducted study on an ergonomic study of permissible weights and loads for female construction workers revealed that the physiological workload of the women construction workers involved in manual lifting and carrying of loads weighing between 16 to $30 \mathrm{~kg}$ was graded as moderately heavy to very heavy. It means in farm activity-transporting of harvested crop manfully also comes under moderate heavy to heavy category. The major health problems related to abnormal working posture are the 'problems of aches' of the musculo-skeletal system. While working in abnormal postures such as bending, stooping, twisting etcit is likely to cause many health problems particularly in the musculo skeletal system in the long run. These may lead to body deformities.

\subsection{Body muscular pain in selected farm activity}

Body muscular pain for lifting of harvested wheat crop from the field was measured and dwelt in Table 4. While performing the farm activity all the influenced body parts were covered in the present study.

A specially designed body map was also used for assessing the body problem faced by the farm women while performing the farm activity-collecting and lifting harvested bundles of wheat crop from field to the threshing area. Maximum body parts were adversely affected in $T_{1}$ (exiting practice) method as compare to $\mathrm{T}_{2}$ (manually hand drawn multipurpose trolley) and $\mathrm{T}_{3}$ (refined trolley with larger wheel diameter). Fingers/palm and cervical point were most affected in $T_{1}$ fallowed by wrist muscles and lumbar point i.e. lower back. It was minimized in $\mathrm{T}_{2}$ and $\mathrm{T}_{3}$ method. Head and thigh muscles were list affected as compare to other body part in $\mathrm{T}_{1}$ method. In case of body discomfort an experiments conducted at Haryana of farm women, reported that women felt very sever to pain in shoulder joints, upper back and lower arm specially while drawing water. Pain was more evident in neck, upper arm, shoulder joints, calf muscles, while carrying load back home (Anonymous, 1999). Fingers / palm were most affected while lifting the bundles of harvested wheat crop because the minute awns which give etching and burning sensation throughout the day to the farm women while on field. That was the major problem faced by the farm women hence the muscular rating was more for palm / fingers. Next to that cervical point was most affected due to the bending posture while lifting the heavy bundle of harvested wheat crop.

\begin{tabular}{|c|c|c|c|c|}
\hline Sl. no. & Parameters & $\mathrm{T}_{1}$ & $\mathrm{~T}_{2}$ & $\mathrm{~T}_{3}$ \\
\hline 1. & Time (min.) & 60 & 60 & 60 \\
\hline 2. & Frequency & 5 & 5 & 5 \\
\hline 3. & Difficulty & $\begin{array}{l}4.63 \\
(4-5)\end{array}$ & $3.84(3-4.5)$ & $2.83(2-3.5)$ \\
\hline 4. & $\mathrm{DI}^{*}$ & $\begin{array}{c}70.88 \\
(66.66- \\
73.33)\end{array}$ & $\begin{array}{c}65.22 \\
(56.66-70)\end{array}$ & $\begin{array}{c}58.88 \\
(53.33- \\
63.33)\end{array}$ \\
\hline 5. & RPE & $4.73(4-5)$ & $3.73(3-4)$ & $3.26(3-4)$ \\
\hline 6. & $\begin{array}{l}\text { Output } \\
\text { head }^{-1} \text { trip }^{-1}\end{array}$ & $\begin{array}{c}20.53 \\
(16-25)\end{array}$ & $\begin{array}{c}102.73 \\
(73-123)\end{array}$ & $\begin{array}{c}111.03 \\
(85-128)\end{array}$ \\
\hline 7. & $\begin{array}{l}\text { Output (kg. } \\
\left.\mathrm{hr}^{-1} \text { head }^{-1}\right)\end{array}$ & 290 & 1627 & 1752 \\
\hline
\end{tabular}

${ }^{*}$ DI: Drudgery Index. (Figures in parenthesis indicates minimum and maximum values)

Table 4: Body muscular pain in selected farm activity-lifting of harvested wheat crop from the field

\begin{tabular}{llccc}
\hline Sl. no. & Parameter & $\mathrm{T}_{1}$ & $\mathrm{~T}_{2}$ & $\mathrm{~T}_{3}$ \\
\hline 1. & Head & $3.56(2-5)$ & $2.93(2-4)$ & $2.33(2-3)$ \\
2. & Elbow Joint & $4.00(3-5)$ & $3.33(2-4)$ & $2.83(2-4)$ \\
3. & Wrist & $4.20(3-5)$ & $3.46(2-4)$ & $2.73(2-4)$ \\
4. & Fingers/palm & $4.83(4-5)$ & $3.38(3-5)$ & $2.93(2-4)$ \\
5. & Cervical point & $4.40(3-5)$ & $3.46(3-5)$ & $2.73(2-4)$ \\
6. & Lumbar point & $4.16(3-5)$ & $3.23(2-4)$ & $2.53(2-3)$ \\
7. & Thigh muscles & $3.50(2-5)$ & $2.76(2-4)$ & $2.26(2-3)$ \\
8. & Leg/knee Joint & $3.80(3-5)$ & $2.60(2-4)$ & $2.23(2-3)$ \\
9. & Feet/anklet joint & $4.03(3-5)$ & $2.93(2-4)$ & $2.53(2-4)$ \\
\hline
\end{tabular}




\subsection{Economic impact}

Data in Table 5 shows the effect on the efficiency of existing and improved technology on the labour required $\mathrm{ha}^{-1}$ time required to transport the harvested produce of one hectare and net saving to the farmers. It was evident that in both $\mathrm{T}_{2}$ (manually hand drawn multipurpose trolley) and $\mathrm{T}_{3}$ (refined

\begin{tabular}{lccccccc}
\hline \multicolumn{6}{l}{ Table 5: Effect of improved technology on post harvest activity of wheat, working efficiency, time spent and net saving ha } \\
\hline Technology & $\begin{array}{c}\text { Bio-mass } \\
\text { t ha }^{-1}\end{array}$ & $\begin{array}{c}\text { Labour } \\
\text { required } \\
\text { ha }^{-1}\end{array}$ & $\begin{array}{c}\text { Time required to } \\
\text { transport produce 8 } 8 \\
\text { hrs. }^{-1} \text { labours }\end{array}$ & $\begin{array}{c}\text { Cost of } \\
\text { transportation } \\
\text { ha }^{-1}\end{array}$ & $\begin{array}{c}\text { Time saved } \\
\text { ha }^{-1}\end{array}$ & $\begin{array}{c}\text { Net saving } \\
\text { ha }^{-1}\end{array}$ & $\begin{array}{c}\text { Working } \\
\text { efficiency } \\
\%\end{array}$ \\
\hline Manual labour & 6.075 & 8 & 3.9 & 741 & 0 & 0 & 99.7 \\
Improved trolley & 6.075 & 4 & 0.93 & 176 & 2.96 & 565 & 417.7 \\
Multipurpose trolley & 6.075 & 4 & 0.86 & 163 & 3.03 & 578 & 454.5 \\
SD & & & 1.73 & 330 & & 195.1 \\
Mean & & 1.9 & 360 & & 323.9 \\
\hline
\end{tabular}

Table 6: Correlation between age, drudgery and output in existing and improved technology

\begin{tabular}{lcccc}
\hline parameters & \multicolumn{2}{c}{ Existing method } & \multicolumn{2}{c}{ Improved technology } \\
\hline & $\begin{array}{c}\text { Drudgery } \\
\text { index }\end{array}$ & Output & $\begin{array}{c}\text { Drudgery } \\
\text { index }\end{array}$ & Output \\
' $\mathrm{r}$ ' values & -0.13 & $0.74^{*}$ & -0.15 & -0.002 \\
' $\mathrm{T}$ ' values & 0.735 & 5.88 & 0.84 & 0.49 \\
\hline
\end{tabular}

"Significant at $(p=0.05)$

trolley with larger wheel diameter) the time required is almost $33 \%$ less as compared to the $T_{1}$ (exiting practice), cost of transportation dropped from ₹ 741 to ₹ 176 and ₹ 163 , and the working efficiency is almost four times. This leads to higher net saving ha ${ }^{-1}$ and, hence, the cost of production of wheat can be reduced to some extent along with the reduction in drudgery involved in the arduous work being performed by farm women. Similar finding on other aspects farm mechanization have been reported by Alam, 2001 in the status report entitled "Future requirements of agricultural machines for mechanizing agriculture"

3.6. Correlation between age, drudgery and output in existing and improved technology

Correlation values and ' $\mathrm{t}$ ' values showing the relationship between age, drudgery and output of the activity in existing and improved practice is given in Table 6. It is crystal clear from the table, that there was a significant correlation in age and output $\left(\mathrm{t}=0.74^{*}\right)$ in the conventional method of handling the harvested wheat from the field. It again indicates the high drudgery involved in the field activity. The same results were also obtained in ' $\mathrm{t}$ ' values also (5.88).

\subsection{Comparison between existing and improved practices} based on respondents feedback

At the end, comparisons between existing and improved practice based on respondents feedback was given in Table 7 which indicates that maximum negative effects faced by the respondents were more in existing practice as compared to the improved technology. As the study showed that it minimises

\begin{tabular}{|c|c|c|}
\hline Sl. no. & Existing & Improved \\
\hline 1. & $\begin{array}{l}\text { Skin disorders, such as scabies, marked by intense irrita- } \\
\text { tion and itching specially at hand and palm muscles }\end{array}$ & $\begin{array}{l}\text { Minimises body itching problems and avoid irritation } \\
\text { senses. }\end{array}$ \\
\hline 2. & Heavy load on wrist muscles/palm & $\begin{array}{l}\text { Loads were carried out through trolley, hence the muscles } \\
\text { were least affected. }\end{array}$ \\
\hline 3. & $\begin{array}{l}\text { Body muscular problems were more particularly at Cervi- } \\
\text { cal (Upper part) and hand muscles were affected more }\end{array}$ & $\begin{array}{l}\text { Loads were carried out on trolley, so the other body parts } \\
\text { were affected less. }\end{array}$ \\
\hline 4. & $\begin{array}{l}\text { More energy consumable activity which leads to drudg- } \\
\text { ery. }\end{array}$ & $\begin{array}{l}\text { Less Energy required which minimises the drudgery } \\
\text { involved in the activity. }\end{array}$ \\
\hline 5. & $\begin{array}{l}\text { Due to the sudden climatic change, the harvested wheat } \\
\text { has to be collect within short span of time to avoid the } \\
\text { losses. }\end{array}$ & $\begin{array}{l}\text { Maximum load was carried out in the single trip which } \\
\text { covers more area within limited time which avoids the crop } \\
\text { losses due to climatic change on harvested wheat crop. }\end{array}$ \\
\hline 6. & Required time for completing the field task was more & $\begin{array}{l}\text { In a single trip of trolley maximum load were carried out } \\
\text { and it covers maximum area in a single trip. }\end{array}$ \\
\hline 7. & - & $\begin{array}{l}\text { Multipurpose trolley useful in other field operations also viz. } \\
\text { washing of horticultural crop specially roots and tubers. }\end{array}$ \\
\hline
\end{tabular}




\begin{tabular}{|c|c|c|c|}
\hline S1. no. & Existing & & Improved \\
\hline 8. & & - & $\begin{array}{l}\text { It helpful in carrying vegetable, flowers and other } \\
\text { horticultural crops. }\end{array}$ \\
\hline 9. & & - & $\begin{array}{l}\text { To operate on field it is easy to handle and women friendly. } \\
\text { Hence, it can be operated by any family member. }\end{array}$ \\
\hline 10. & & - & $\begin{array}{l}\text { Saves time, energy, body disorders, exertion and gives more } \\
\text { output, minimises drudgery }\end{array}$ \\
\hline 11. & & - & $\begin{array}{l}\text { Eco friendly with the atmosphere because it is manually } \\
\text { operated and no diesel or petrol is required. }\end{array}$ \\
\hline 12. & & - & Economic and anybody can able to purchase it. \\
\hline 13. & & - & Easily available in local market. \\
\hline
\end{tabular}

body itching problems and avoid irritation senses which were the measure problem as quoted by the farm women. In case of other body discomfort also it was observed that cervical point was less affected in advanced technology $\left(\mathrm{T}_{2}\right.$ and $\left.\mathrm{T}_{3}\right)$. It reduces the time hence it can be implied that it could be minimising the drudgery also. Other important factors were it saves time, coverage area was more, output and work efficiency was also quite satisfactory and eco-friendly with farm women as well as environment also. This trolley can be useful to the other crops also especially for horticultural crop because it was purposely designed for fulfilling the requirements of farm women for completing the various farm operations viz., washing of roots and tuber crops, for transporting the floricultural and vegetable crop from field etc.

\section{Conclusion}

Specially designed and developed multipurpose trolley minimizes drudgery by $12 \%$, body muscular system of body parts. It covers $38.23 \mathrm{~m} \mathrm{hr}^{-1}$ area and gives $111.03 \mathrm{~kg} \mathrm{hr}^{-1}$ output which was $90 \mathrm{~kg}$ more than existing practice. The ' $\mathrm{r}$ ' and ' $\mathrm{t}$ ' values showed significant relation in age, drudgery and output. It can be concluded that the multipurpose trolley is economic, easy to handle, covers more area, more suitable to wheat crop and eco friendly to farm women.

\section{References}

Alam, A., 2001. Post-harvest management of agricultural produce and by-products. Paper presented in Agricultural Science Congress on Sustainable Development of Mountain Agriculture, AAU, Guwahati, 4-7 April, $1-28$.

Anonymous, 1999. Report of All India Coordinated Research Project (AICRP) on Women's drudgery, Dept. of Family Resource Management, College of Home Science, Haryana Agricultural University, Hisar, Haryana, India, 60.

Anonymous, 2004. Proceedings of National Seminar on Drudgery Reduction for farm women in Rice Farming, NRCWA. 1-98.
Badve, G.P., 1999. Inventory Analysis of working pattern of rural women in homes and farm. M.Sc. (Home Science) Unpublished Thesis, Dept. Home Science, College of Home Science, 1-155.

Bhatnagar, A., 1995. An ergonomic study of permissible weights and loads for female construction workers. Unpublished Ph.D. thesis, SNDT Women's University, Mumbai, 1-199.

Boki, V.I., 2000. Physiological stress on farm women in the performance of Household and farm activities unpublished M.Sc. Dissertation. MAU, Parbhani, 1-168.

Deere, C.D., 2005. The Feminization of Agriculture? Economic Restructuring in Rural Latin America (Occasional Paper 1). Geneva: United Nations Research Institute for Social Development. ISBN 92-9085-049-3. Available at www. unrisd.org/publications/opgp1.

Dipankar, D., 2009. Drudgery Reducing Technology of Farm Women. Manual-ICAR Winter School. Gender Empowerment in Agriculture, Division of Agriculture Extension. IARI, New Delhi, 1-134.

Kulakarni, S.D., Gite, L.P., 2009. Drudgery Reducing Equipment for Farm Women. Reading Material of ICAR winter school on Gender Empowerment in Agriculture. Division of Agricultural Extension, IARI, New Delhi, 83-91.

Katz, E., 2003. The Changing role of women in the rural economies of Latin America. In: Davis, B.(Ed.), Current and Emerging Issues for Economic Analysis and Policy Research (CUREMIS II: Volume 1-Latin America and the Caribbean. Economic and Social Department, FAO, Rome. ISBN 92-5-104998-X.

Saha, A., 1990. Ergonomic and Scope: Physical health and neuroticism among women engaged in home based production of chicken embroidery. Social Indusrties Research 32(2), 179-191.

Tandon, N.S., Viegas, 1993. A study on income generating income strategies of socially underprivileged women in a selected slum of Bombay. Journal of Education Research and Extension 30(2), 94-108. 